\title{
A POLITICS OF HABITABILITY: Plants, Healing, and Sovereignty in a Toxic World
}

\author{
STACEY ANN LANGWICK \\ Cornell University \\ (D) http://orcid.org/0000-0003-1688-8561
}

What first struck me was the lushness. I had stepped through the gate and into the compound of the NGO Training, Research, Monitoring and Evaluation on Gender and AIDS (TRMEGA), just a few hundred meters off the main road running east out of Arusha, Tanzania. The label of an herbal formula, imarisha afya yako ("strengthening your health" in Kiswahili) had led me to this address.

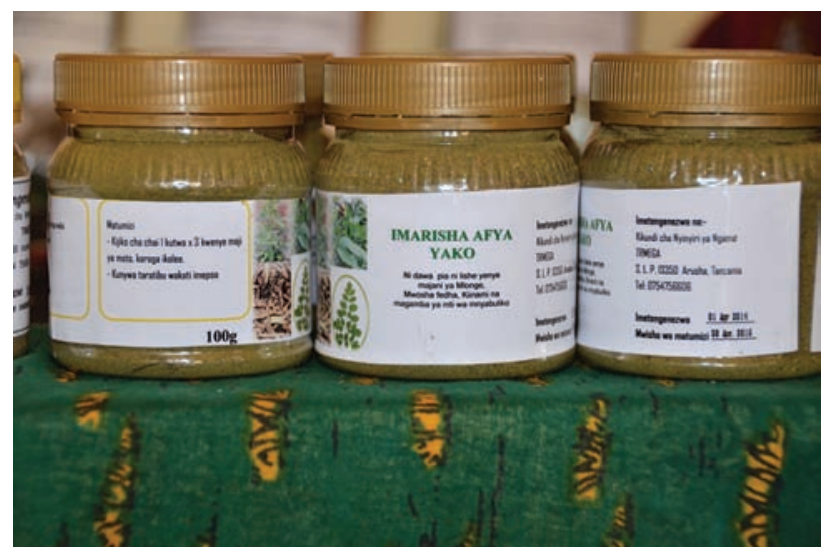

Figure 1. Imarisha afya yako: an herbal formula whose components are grown, processed, and packaged by TRMEGA, Maji ya Chai, Tanzania. Photo by Stacey Ann Langwick. download, save, reproduce, and transmit for noncommercial, scholarly, and educational purposes. Reproduction and transmission of journal content for the above purposes should credit the author and original source. Use, reproduction, or distribution of journal content for commercial purposes requires additional permissions from the American Anthropological Association; please contact permissions@americananthro.org.DOI:10.14506/ca33.3.06 
At TRMEGA, unlike at the herbal or biomedical clinics where I also worked, passion-fruit vines covered the fence. Neatly labeled medicinal plants packed narrow beds along the edges of the compound and squeezed into corners of buildings. Chard and a range of other dark green, leafy vegetables grew in a kitchen keyhole garden and burst from sacks placed around the courtyard. A brightly painted sign reading "Maji ya Chai Slow Food Community Garden" sat at the head of a winding path that invited walkers through plots of taro, sweet potato, watercress, and tomatoes.

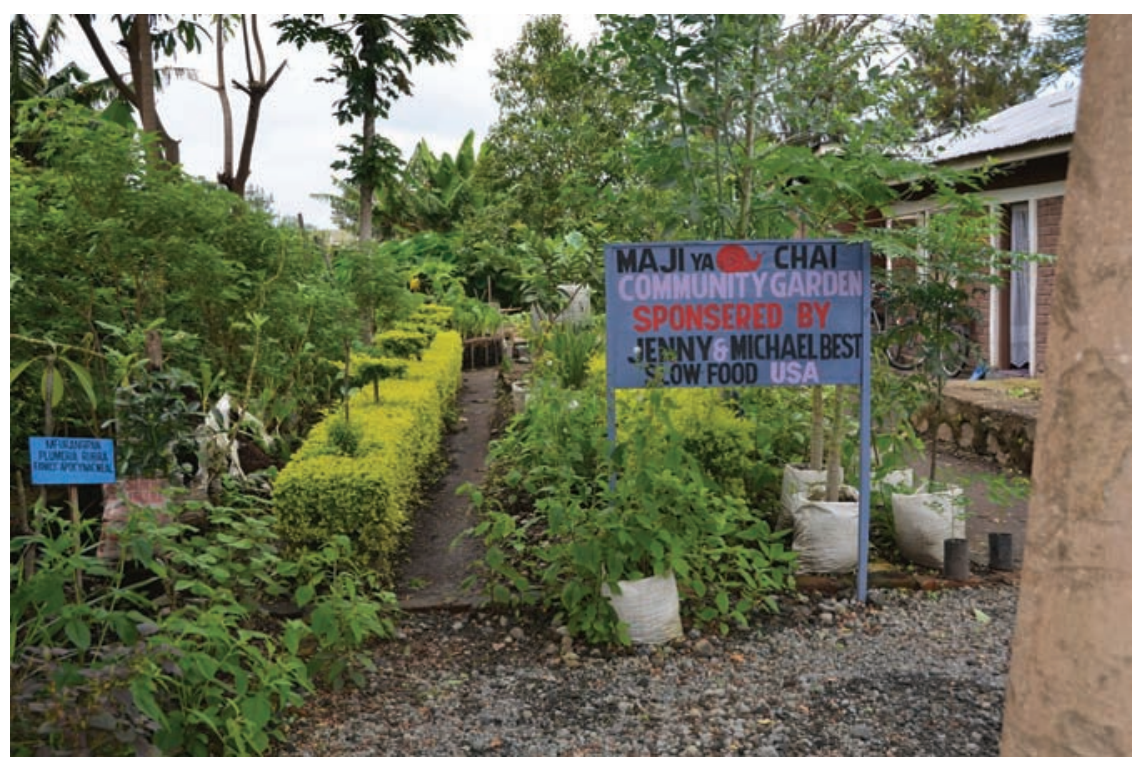

Figure 2. TRMEGA garden, as viewed upon entering the compound at Maji ya Chai. Photo by Stacey Ann Langwick.

While it has taken time to understand the relations constituting this lushness and to follow the alliances suggested in the sign, the garden immediately compelled a reframing of the story of imarisha and the other herbals that sat in piles on a table against the back wall of the office.

Imarisha is one example of the rapidly expanding developments in therapeutic foods or nutritious medicines that are capturing imaginations in Tanzania and beyond. Helen Nguya, the founder of TRMEGA, glosses this new configuration of plant-based healing as dawa lishe: a playful phrase that draws together the more official categories of medicine (dawa) and fortified or nutrient-dense foods (chakula lishe). These therapies heal by feeding, nourishing, strengthening, bringing vitality, 
stimulating growth, enabling endurance. Tanzania is not alone in witnessing a rapid rise in herbals. The World Health Organization (WHO) has estimated that herbals make for a $\$ 60$ billion industry worldwide, and some market forecasters suggest that it stands to grow to a $\$ 140$ billion industry by 2024 (Sharma et al. 2008). Statistics on the market and on industry growth, however, do not capture the work of TRMEGA gardens or elucidate their alliances with food sovereignty movements. Dawa lishe is emerging as an unruly object in the interstices of medicine and agriculture, refusing to accept them as separate fields of knowledge and practice. Dawa lishe is not a return to, or even a nostalgia for, traditional African healing. It is, however, a refusal to forget in the present that African healing has long addressed humans and their environments together. Therapies attend not only to bodies but also to the relations between people, plants, and soil that drive modern economies and frame health. Individual commodified formulas fade in and out of view.

Imarisha and TRMEGA's other colorfully packaged dried-plant remedies draw people, as they drew me, to TRMEGA. The ease with which such remedies can be sold and gifted facilitate introductions to TRMEGA's work. Yet these commodified herbal formulas circulate in the service of complex interventions into the forces that foster vital human and nonhuman communities. Indeed, TRMEGA's garden explicitly destabilizes the commodities produced from regular harvests through the sharing of seeds, cuttings, and saplings across networks of support groups.

The labors of people and plants, as well as the myriad organisms both human and nonhuman that make up healthy soil and fertile communities of pollinators, constitute a central focus of TRMEGA's interventions. As they spread, one out of the other, TRMEGA gardens and the gardens that they catalyze are complex experiments in what constitutes the therapeutic. In the name of healing, TRMEGA gardens explicitly intervene into relationships between plants and people-remaking them in ways that unsettle assemblages built through colonial plantations, national development, and extractive capital. In this, these gardens share a kinship with the rise of various projects in Africa and throughout the global South that draw local knowledge of how to support the flourishing of plants and people together with global ecological and health movements. ${ }^{1}$ These gardens are examples of what Michelle Murphy (2017, 105) has called the "experimental otherwise," and dawa lishe is the unruly object forged in the multiple knowledges, myriad practices, and entangled politics that they draw together. 
Through dawa lishe, Tanzanians are debating the conditions under which life is attenuated, diminished, depleted, exhausted, or drained away in the twentyfirst century, and they are experimenting with ways to intervene in these conditions. The efficaciousness of herbal products and of gardens full of therapeutic foods and nutritious herbs rests in their cultivation of the forms of strength that make places, times, and bodies livable again (and again). Gardens and gardeners are generating a lexicon through which to challenge the techniques of governance unfolded in the name of health. Their efforts, I will argue, articulate an emergent politics of habitability. ${ }^{2}$ Dawa lishe ties the dynamics of human liveliness to those of plants and soils. Through it, Tanzanians work to build relations supporting the possibility of a lushness that situates healing in the cyclical transformations of composition and decomposition. They experiment with ways to inhabit the toxicities that simultaneously enable contemporary life and deplete the very conditions of its ongoingness.

\section{TOXICITY}

Imarisha, specifically formulated to benefit people with HIV/AIDS, contains plants that have been shown to have dense nutritional profiles and a range of biochemical effects with therapeutic implications in laboratory research (Anwar et al. 2007). Yet an account of its potency must also attend to the ways in which it problematizes the toxicity of pharmaceuticals, especially those like antiretrovirals that are to be taken for life. ${ }^{3}$ TRMEGA has a close relationship with a nearby HIV/AIDS clinic. Imarisha is meant to be taken with antiretroviral medications: the herbal formula works alongside antiretrovirals to strengthen bodies so that they can sustain the pharmacological treatments, so that individual bodies can incorporate these medications in ways that exploit their benefits. Members of TRMEGA build their stamina for antiretrovirals through imarisha, as well as their compliance with the clinic's regimes. Imarisha addresses the widespread sentiments in Tanzania that (1) the toxicity of antiretrovirals (which is critical to their capacities to heal) is also harmful, and (2) this harm is not sufficiently articulated through the concept of side effects or fully mediated through the practice of dosage. ${ }^{4}$ Imarisha highlights the double bind out of which Tanzanians are forging dawa lishe more broadly: the very substances used to support modern life also deplete the vital forces from which it comes. ${ }^{5}$

Over the past six years, as I have investigated the rise of dawa lishe, I have come to see its political and therapeutic potency as intimately tied to the ways in which it reconfigures the relationship between toxicity and remedy. Dorkia 


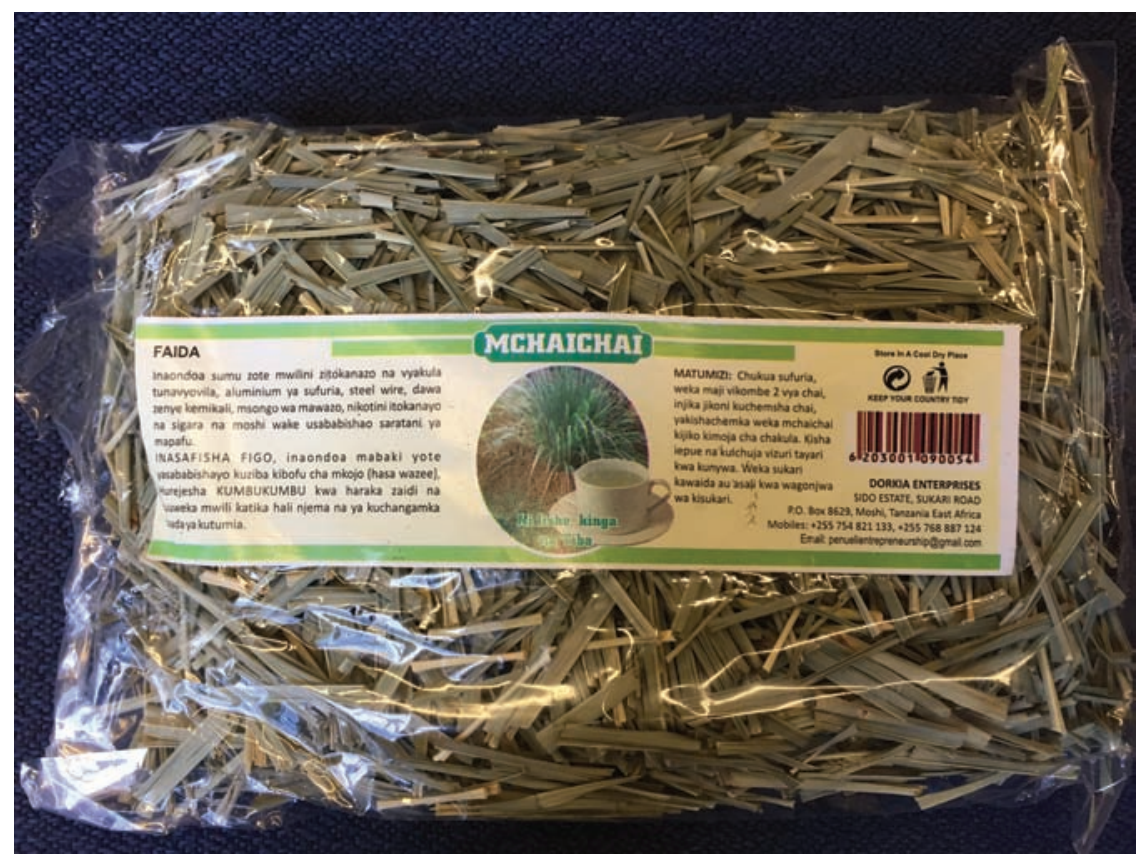

Figure 3. Mchaichai (dried lemongrass) produced and packaged by Dorkia Enterprises, Moshi, Tanzania. Photo by Stacey Ann Langwick.

Enterprises, a small-scale entrepreneurial initiative in northern Tanzania, addresses this directly on the label of its mchaichai (Kiswahili: lemongrass).

It removes toxins from the whole body-those [toxins] that come from the food whose growth we have cut short, aluminum pots, steel wire, chemical medicines [synthetic pharmaceuticals, as well as synthetic fertilizers, herbicides, and pesticides], mental stress, and nicotine, which is from cigarettes and their smoke [and] is the cause of lung cancer. It cleans the kidneys; it removes all the residue stopping urine/plugging up the bladder (especially in elders). It returns a quicker memory and it puts the body in a good and lively state after using.

The problem articulated here is that eating, drinking, cooking, healing, and breathing all involve ingesting toxins. Mchaichai offers a way to mediate the forms of complicity and contamination that are constitutive of twenty-first-century lives and bodies. Like imarisha, it is not a targeted or singular curative remedy, but rather a therapeutic tea to be included in the everyday rhythms of nourishing. 
This sense that toxins saturate everyday life compels herbal producers not only to address the effects of toxins in individual bodies but also to pay attention to how the plants in their remedies are grown and processed. As toxicity becomes respatialized in this way, it focuses attention on that which is left behind as the very ground through which new or alternative life might then be nourished, coaxed, and cultivated - or cut off, deprived, and attenuated. Producers' commitments to sustainable agriculture - in particular, to the use of organic cropmanagement practices, composting, and seed sharing-generate the concrete practices through which dawa lishe articulates toxicity as a condition of modern life and the substance of ethical engagement. ${ }^{6}$ By attending to the liveliness of soils and seeds, as well as to their economies, Tanzanians reflect on and labor over the relations that constitute toxin and those that constitute remedy.

This problematization of toxicity by herbal producers in Tanzania highlights a friction within public health studies of environmental exposure. The latter have proven important in illustrating the uneven distribution of harm in our world, both nationally and internationally, by mapping disease prevalence data alongside the location of industrial contaminants and toxic waste. This data has supported the development of environmental regulations, a conceptualization of the true cost of industrial production, the monitoring of industries, and (in the best of cases) the ability to hold them accountable to the people they affect. In this work, the image of individuals free of toxins provides both a ground for normative legal intervention and benchmarks for measuring success. Yet: is there a we that can be held safe against all else? A growing scholarship on toxicity and chemical exposure is challenging philosophical investments in the possibility of discrete, bounded objects and subjects that undergird the ideal of bodies that can be whole, independent, authentic, and pure, as well as their versions of politics (both progressive and conservative). ${ }^{7}$ Expanding Bruno Latour's (1993) argument about the practices of purification that have been central to the project of modernity, Alexis Shotwell (2016) captures this argument in her assertion that we have never been pure. The processes of purification built into scientific and juridical knowledge-making practices structure our forgetting of this fact. Living through toxicity as a condition means remembering. It means remembering that the work it takes to purify human bodies and synthetic chemicals is embedded in the work it takes to solidify a long chain of ontological distinctions between us and them, subjects and objects, and science and culture. Living through toxicity as a condition means remembering that this work has proven critical to the formations of contemporary hierarchy and privilege and the notions of contamination, corruption, and con- 
tagion that justify their maintenance. ${ }^{8}$ Such remembering challenges any easy recognition of a we who has a right to live uncontaminated, of a toxin separate from and threatening this we, and of a neutral position from which to adjudicate this separation (Fortun 2001; Petryna 2002).

Shotwell's research is helpful because it clarifies why purity politics do not offer a space to argue and act that many Africans find compelling. ${ }^{9}$ The forms of forgetting developed through practices of purification have justified violence and dispossession through colonialism, nationalism, postcolonial development, and humanitarianism in Africa. How we grapple with toxicity is thus a question of how we remember and whose remembering matters (Agard-Jones 2016). Postcolonial memories shape how African publics hear both official news stories and circulating rumors of the continued spraying of DDT (Cone 2009), the large graveyards of e-waste from the United States and Europe (Schmidt 2006; Redfern 2010; Minter 2016), the international trade in radioactive waste (Clapp 1994), the use of cyanide and mercury in mining (Campbell et al. 2003; Belem 2009), and chemical fertilizers, pesticides, and herbicides in large-scale agriculture (Tilman et al. 2001; Mwegoha and Kihampa 2010). Tanzanians are well aware that the lack of regulations on known toxins is exploited as an asset throughout the continent. This is before leakage into informal markets, such as when the surplus pesticides used by the large-scale flower farms in Arusha made their way into small agricultural shops and were picked up as a cheaper alternative to protecting tomatoes in local kitchen gardens. ${ }^{10}$ In this space, a politics of purity, an ideal of an uncontaminated body, is unthinkable both practically and politically. More evocative is the mchaichai that "returns a quicker memory and it puts the body in a good and lively state after using." More evocative is the invitation to take in a plant and attune to its transformative potential. This is not a nostalgia for tradition but a call for memory, for a remembering that relations between plants, people, and place have not always been as they are, that they were reorganized through colonialism and continue to be stabilized through large-scale (plantation) agriculture. Liveliness might be found by inserting the body into alternative economies of people and plants.

For Tanzanians, such remembering also means that the toxicities that compose the everyday are not only the result of capitalism's offloading of its harmful waste to Africa but also the social-material effect of efforts designed to address insecurity, poverty, and disease. The pesticides and herbicides in food, the growth hormones fed to modern chickens, tissue cultures injected into banana plants, the aluminum pots used in everyday cooking, the hybrid (at times, genetically mod- 
ified $^{11}$ ) corn whose reproductive strength decreases over generations, and the pharmaceuticals required to address chronic diseases (whether HIV, hypertension, or diabetes) and provide birth control are all held responsible for forcing modern bodies to bear complicated toxic loads. Approaching toxicity as a condition rather than an anomaly, however, does not mean an acceptance of sickness, pollution, injustice, poverty, and death. It does mean that interventions focused narrowly on modes of recognition (and management) are not sufficient.

Through dawa lishe, the interpenetrations of plants and people become a concrete space from which to explore "the enmeshment of flesh with place" (Alaimo 2016, 1) by elaborating a notion of healing that recognizes our ontological inseparability from the world. This starting point was brought home to me by a woman working at one of the herbal clinics where I have been conducting research since 2013. Through our many hours together in the face of the pain of those seeking help at the clinic, in the camaraderie and joys of collective efforts to support them, in the rush of multiple demands, and in the boredom of long hot afternoons, we had grown very fond of one another. One afternoon, she shared her concern about the toll my trips back and forth between Tanzania and the United States would inevitably take on me. The dis-ease of my body, as it had to adjust and readjust to these different environments, would benefit from some attention. To cultivate this dual orientation, she recommended a strategy that she had learned from a German missionary in the area. When I traveled back to the United States, my friend told me, I should take a little dirt from Tanzania. On arrival, I should mix it with a little water from the United States and drink it. On my return to Tanzania, I should do the opposite: bring U.S. dirt, mix it with Tanzanian water, and consume it. This way, my body would be constituted in the interstices of these two lands; it would be of both places and could make the corporeal translations and shifts necessary to my constant returns.

The vulnerability of a body is not only implicated in toxic substances but also in the very movements that give rise to the conditions and labors through which strength is constituted. In his effort to account for the toxic in North America, Nicholas Shapiro $(2015$, 372) has argued that "bodies are sites of both actively absorbing the world and being put into motion by its constituent medley of human and nonhumans." Healing, then, is not necessarily limited to managing that which bodies absorb. Healing might also mean intervening in human-nonhuman relations to affect how specific bodies are put into motion. Dawa lishe emerges as therapeutic as it (re)shapes the formations of time, space, and materiality through which bodies live and labor. In Tanzania, healing is raising questions 
of habitability, as it works through and against the politics of exposure that have shaped "late industrialism" (Fortun 2012). ${ }^{12}$

\section{THE PLANTS AND THEIR INSTITUTIONS}

Dawa lishe has a complicated relationship to the state-recognized category of traditional medicine and its institutional trajectories. ${ }^{13}$ Producers of therapeutic foods and nutritious medicines draw on indigenous plants, as well as those that have migrated to the continent. They are inspired by local healers, as well as by books on functional foods, web-based investigations, scientific research at African, European, and North American universities, local Chinese healers, visiting Indian spiritual leaders, permaculture workshops, and sustainable agricultural practices. ${ }^{14}$ Rarely interested in acting as custodians of the past, producers seek a more dextrous and subtle position that enables response to the ways past relations have shaped the bodies and landscapes of the present. ${ }^{15}$ Many mobilize the form of the NGO to reframe older social and political institutions in an effort to initiate generative spaces for action.

For instance, while Helen Nguya is not a traditional healer by her own or anyone else's account, the process through which she came to found TRMEGA and grow into the work she does there echoes the embodied transformations involved in African healers becoming expert through their own illness and healing. A physical collapse set in motion the conditions of possibility for TRMEGA. The stress of more than a decade of demanding work and long hours as a director of social-service programs for the Roman Catholic Church in the northern part of Tanzania, combined with two intense years during which she organized and worried over the care of her children back in Tanzania while she was in Europe earning a master's degree, exhausted Nguya. She did not have the strength to bear the shock of the deaths of her mother and sister. She collapsed. Suddenly, she could not stand or feed herself. Her kin nursed her in her marital home of Maji ya Chai. Nguya's healing slowly drew her back to the garden. First, as she sat in the garden and then, eventually, as she put her hands in the dirt, she felt that she began to heal. Or, as she tells it, she started to remember those things that had fed her, had given her vitality when she was younger.

From her initial efforts to reimagine a life in which she could do meaningful work and sustain her strength emerged the vision of TRMEGA. Among her extensive portfolio of social-service programs was a church-supported HIV clinic. She was moved by the story of a man who had sought treatment through this clinic and had come to feel that he was capable of continuing his life with AIDS, 
that his diagnosis was not a death sentence. Together, they began reaching out to others who had been diagnosed with HIV/AIDS. Through their initial efforts in 2009, Nguya began to see a particular set of needs and possibilities. She explained:

I realized that some had problems, and I didn't have the funds to help. They had clothing needs and food needs. So I told my family and friends. Some contributed clothes. Some gave me shoes. Some donated domestic utensils. Some donated food. They came and they saw [my work]. They were amazed and gave me maize flour and whatever they had. I taught those who gathered about nutrition. We had already planted some plants. I taught them how to cook them. They came here [to my garden in Maji ya Chai]. We ate together and participated. This made them more active. After that we saw that it would be better to teach them about herbs, and that they should not only practice it here, but also at their homes. And those who had land around their homes, we gave them things to plant.

Thus emerged the garden as object and intervention. Gardens are not exactly a solution to the problems that Nguya perceived, but something more and something less. For TRMEGA, gardens - organic, cultivated without chemical pesticides and synthetic fertilizers, full of therapeutic plants, spreading from one to another and growing up around homes and schools - are remedy and relation, resource and momentum. They constitute the very material of individual, institutional, and community extension. Gardens offer a response to the attenuation of life; their answer is a thickening, a density, a multiplicity that one might experience at times - like when walking through the gate of TRMEGA - as lushness.

Today, the garden at TRMEGA's headquarters serves as a community garden for the members of TRMEGA support groups and a Slow Food demonstration garden to introduce new members, school groups, and other visitors to the plants and principles of sustainable agriculture. Experiments with recycling kitchen water, sack gardens, and composting were always underway. Bees have been introduced, both larger honeybees and smaller, stingless African bees. Medicinal plants are neatly labeled in both Swahili and the local language of the area where Nguya learned of their therapeutic potential. In the shade of the pavilion, medicinal herbs as well as therapeutic foods are dried and processed into TRMEGA remedies. This garden also generates the cuttings, seeds, and saplings used to stimulate other gardens. 
The contents of this garden embody a lifetime of living with and working with plants. Both in its shape and in the plants that populate it, Nguya's garden innovates older ways of organizing landscape through the residential farms of her childhood. Nguya grew up in Kagera. She helped her grandfather as he tended banana trees, which not only supplied the primary staple food crop but also structured the spatiality of village life and the masculine forms of land ownership that drove it. ${ }^{16}$ Nguya first learned to identify and collect medicinal herbs with her grandmother, a traditional midwife. She has transplanted some of these plants to Maji ya Chai. Others she continues to get from Kagera, sometimes going herself, at other times asking a nurse in the health center to collect a desirable herb for her and then send the harvest by bus. The novel collectives fostered through the rapid expansion of NGOs in Tanzania since the 1990s have enabled Nguya to combine the ways that the gendered landscapes of Buhaya villages structured reproduction, nourishment, and expansion with the work of global projects. While her home in an adjacent lot is surrounded by banana trees, her TRMEGA garden is not. The contents of TRMEGA's garden might be better seen as an extension of the gardens Buhaya women would cultivate in the grasslands outside the village. ${ }^{17}$ The plants she learned from her grandmother grow together with the charismatic plants now used for therapeutic purposes globally, inputs from nutrition initiatives and development projects and vegetables that make the many stews accompanying starches throughout Tanzania — all in a space shaped by a set of practices often glossed as "sustainable agriculture."

The gardens at TRMEGA are in a complicated conversation with older social-political practices of dwelling and newer global ecological practices. Nguya's knowledge of these ecological techniques first grew out of her participation in an NGO called Women Development for Science and Technology Association (WODSTA). In the 1980s, Nguyga worked with a group of prominent women leaders to found WODSTA. In those early days, President Julius Nyerere's wife, Maria Nyerere, joined their efforts. The association has always focused on "grassroots women," meaning rural and often disenfranchised women. Sustainable agricultural practices were central to the mission of the organization from its inception. Because of this work, Nguya was first invited to the biennial Slow Food gathering in Turin, Italy in 2004. She returned in 2008 and has gone to each subsequent gathering. These days she generally goes with Rose Machange, who runs the gardens and does outreach for WODSTA. In the 1980s, Machange was one of the grassroots women whom WODSTA had contacted. Initially part of a support group, she rose to lead this group and then to mobilize others. 
Each of these gardens forms part of the Ten Thousand Gardens for Africa project, one of the flagship initiatives of the Slow Food Foundation for Biodiversity. In 2011, while in Tanzania to celebrate the first gardens (one in Dar es Salaam and one in southern Tanzania), Italian staff members visited Nyuga's compound and saw the TRMEGA garden. They ate with her and talked about their vision for Ten Thousand Gardens for Africa, asking if she would volunteer to be the convivium coordinator for the northern region. Although coordinators are not paid, this position would enable Nyuga to solicit limited funds for material enhancements to expand the network of gardens, such as hoes, wheelbarrows, watering cans, and fencing. In addition, the foundation strives to train convivium coordinators and other leaders and to support travel to meet other communities. These connections draw members into other Slow Food projects like the Arc of Taste, an effort to catalog indigenous foods and recognize groups whose work ensures their endurance. A women's group that Machange leads, called UMANGU, has recently succeeded at having their African stingless bee honey accepted into the Arc of Taste. It also oversees projects like the new traditional foods shop that sells various products from the women's support groups Machange runs. When Nguya and Machange travel, be it locally to the gardens or internationally to Kenya, Uganda, Italy, Ethiopia, or India, seeds often return in their pockets. Even after decades of friendship, it seems they rarely leave one another's gardens without something in their hands. Knowing them both for the past four years has allowed me to witness not only their attentiveness to plants but also how they move through the world with them.

Throughout its existence, TRMEGA has grown, extending its work through a variety of organizations. Originally, Nguya's wide-ranging connections with the Catholic dioceses and their projects animated TRMEGA's formation, and they continue to provide fertile ground for growth. Currently, Nguya is folding some of the projects and energy of the Slow Food Foundation for Biodiversity into TRMEGA's work. Such entanglements have been further extended and reinforced by Nguya's connection to WOSTRA and by her friendship with Machange. The interpenetrations of these institutional trajectories also carry with them certain orientations toward history-here, Catholic social-justice agendas, a global movement for culinary diversity and food sovereignty, and a postcolonial, nonaligned socialist drive for self-sufficiency. Connections are partial, situated, and embodied, built through personal histories of resilience, friendship, and striving, as well as of inequality, abuse, and sickness. It is into this density of relations 
(institutional, human, and botanical) and these storied spaces that TRMEGA welcomes people.

\section{THE GARDENS AND THEIR REMEDIES}

Early in TRMEGA's formation, Nguya met Jane Satiel Mwalyego, who at the time was very weak. Her husband had died in 2002. She was, in her own words, "living with much stigma" (Saas 2014). She had stopped taking her antiretroviral drugs in the midst of these pressures and the demands of providing for her children as well as her nieces and nephews, whom she had taken in after her brothers had died from AIDS. She tells a story of decline and searching, and of visiting a range of healers. Eventually, she lost the strength to farm. At times, she could not even rise from bed to cook. Both of her parents had passed away. She ran out of money and found herself without enough to be able to feed the children in her household or herself. The vitality that had sustained her life and that of others grew more and more attenuated; the courtyard of her home grew sparse. When Mwalyego reflects on this time, she describes loneliness, and isolation, and anger-anger at healers who took her money, time, and waning strength. But she marks 2010 as the turning point, in which she met Nguya and gradually began building up relations with people and plants.

At the time, TRMEGA focused on teaching people with HIV to "together leave aside stigma” (Kiswahili: nawafundisha waondokane na unyanyapaa). The organization sought to create spaces where people with AIDS could, in its own terms, "get used to each other," gain the confidence to talk with one another, and "share what is in their hearts." This language resonated with that of HIV/ AIDS support groups. Indeed, Nguya did receive some external support for such work. Most prized at the time were bicycles that would ease outreach efforts and enable more connections. Yet an account of TRMEGA's approach at this time must acknowledge that stigma here was in translation, a sort of boundary object that often emerges as NGOs appeal to global initiatives in efforts to design local projects and take up medicalized concepts to support interventions into everyday life. The way that TRMEGA actualizes stigma differs from the way that stigma is actualized through psychosocial research and public health programming. The histories of discrimination and social sanction that structure stigma (unyanyapaa) are most accurately accounted for through material instantiations. Stigma, for TRMEGA, glosses a thinning of social relations and all matter of life entangled with them-human, plant, and otherwise. Rather than seeing stigma as a psychosocial phenomenon, a judgment of the mind that can be fixed by addressing 
ignorance, TRMEGA takes up stigma as a relational phenomenon. It entails a turning away or attenuation of involvement that must be fixed by addressing the density of interconnection through which life is generated. While TRMEGA gladly folds education into its agenda, the efficacy of its efforts lies as much or more in the gatherings convened than in the correction of false beliefs or the transmission of information. Addressing stigma requires a series of encounters that interpolate one into vital, mutualist relations with things, people, and plants. Nguya introduced Mwalyego to mlonge - the Kiswahili word used for many species of moringa, but here for Moringa oleifera in particular. She remembers that Mwalyego's dramatic response to the plant was the first time that she "saw the power of mlonge." ${ }^{18}$ Mwalyego gained strength, resumed her antiretrovirals, and started gardening again. She was able to support her children and her brother's children. Her physical and social life thickened; the landscape around her house grew denser. This experience strengthened the role of mlonge and the centrality of the gardens as remedy in TRMEGA's work.

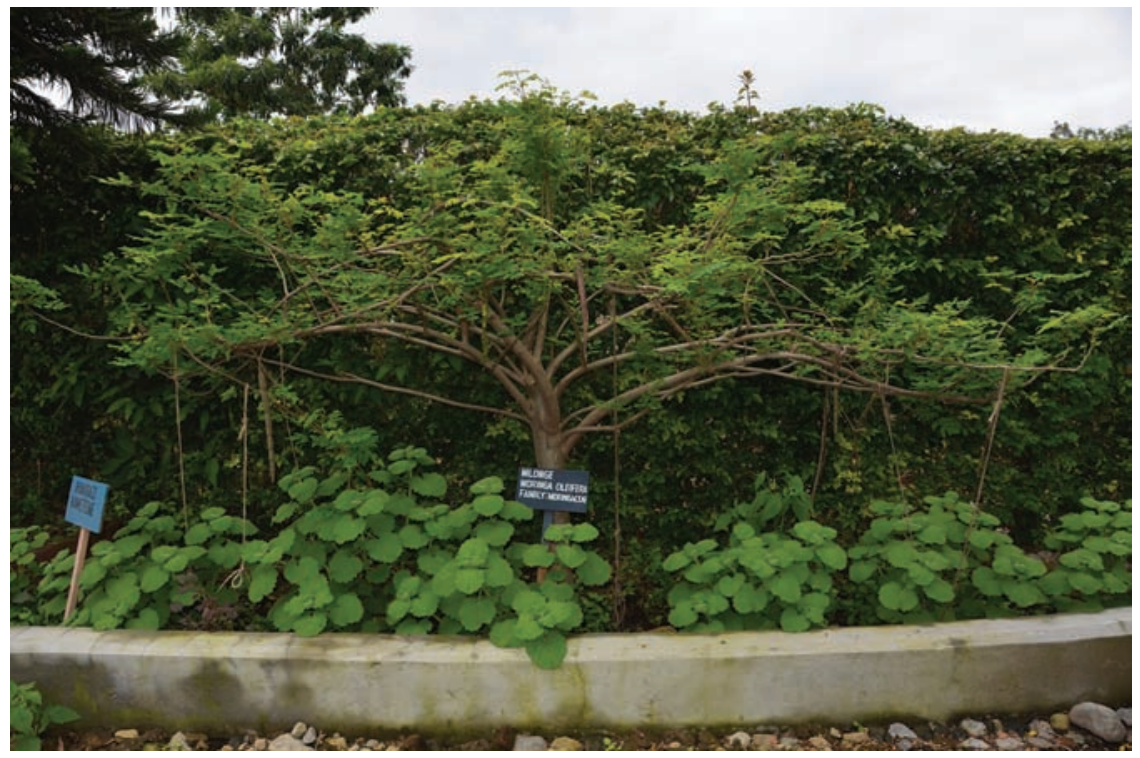

Figure 4. Mlonge (Moringa oleifera) in the garden at TRMEGA headquarters in Maji ya Chai. Photo by Stacey Ann Langwick.

When I first came to know Mwalyego, her life had grown lusher. She had come to embody the transformations possible through TRMEGA and its gardens, and to serve as a catalyst for others. In 2016, when an anonymous donor gave 
TRMEGA a plot of land so that the organization might increase its production, Nguya asked Mwalyego to live on the property and tend the gardens. In addition to a house, Mwalyego received space to grow some of her own food. Using seeds, saplings, cuttings, and tubers from other gardens, she built up a second demonstration garden and developed plans for a much larger production garden. Mwalyego's daughter and grandchild moved in with her. As a new Slow Food community garden, this second TRMEGA garden attracted some additional investments. Mwalyego started a chicken coop and developed a vision of acquiring goats. One of the first luxuries at the house was a long, thin wooden bench where TRMEGA members and others could gather, where Mwalyego could teach, and where collective work could be organized.

During the past few years, much of my fieldwork involved Nygua, Mwalyego, and me filling my vehicle with plants and distributing them. Many of our best conversations arose as we drove through the region delivering cuttings, seeds, and saplings - as we extended TRMEGA's garden outward. Our activities catalyzed other patches of lushness in orphanages, street children's homes, elementary schools, and the homes of people planning community gardens of their own. Plants were delivered, along with a great deal of advice and problem-solving skills, as we tromped around the spaces to be planted. Nguya instructed on composting, organic pest and fungi management, irrigation and drainage, intercropping and more. She brought both nutrient-dense vegetables and medicinal herbs. After these long and detailed walks through the gardens, conversations regularly turned to health, to the therapeutic benefits of plants. Over tea, we would speak of the ways they cured and strengthened. Such meetings never stood alone; they always marked moments in long and involved relationships. Some had started a decade or two earlier through Catholic Church projects, while others emerged from newer, secular connections. Yet all gardens required tending and ongoing relationships.

While individual gardens and their gestures were limited, gardens were sites from which plants and relations could be extended. One TRMEGA member, who lives on the outer reaches of Arusha, started a community garden for members on his land. The medicinal teas he makes for his parents facilitate his caring for them. His neighbors drop by to explore ways that they might use plants to support the health of their families. Other gardens are larger. For instance, the garden at the Watoto Foundation, a home for male street children run by the Catholic Church, is quite established and substantial. The residents eat from the garden and make products to sell. Many of these boys go home during breaks. They have 
been encouraged to bring mlonge saplings home and to plant them at their parents', relatives', and neighbors' houses.

\section{IMMIGRANT NATURES, COMPOSTING FUTURES}

Mlonge, the tree that was so powerful in Mwalyego's story, animates TRMEGA's current work and their Slow Food gardens. The saplings sprouting in small plastic bags that line the wall of the garden in Maji ya Chai lend themselves to travel, to manifesting extensions and initiating new spaces. This mlonge tree is also known as Moringa oleifera, a tree native to the foothills of the Himalayas in northwestern India. The species likely traveled to Tanzania along numerous routes, involving both land and sea. Gujarati traders arrived in Tanzania in large numbers in the nineteenth century. Indians were also brought to East Africa as indentured laborers, many of whom worked on the Kenya-Uganda railway around the turn of the twentieth century. Even before these migrations, however, Moringa oleifera may have found its way to Tanzania along earlier trade routes, whether from Egypt, South Africa, or through centuries of Indian Ocean exchange. In more recent times, Moringa oleifera has extended its reach through international nutrition and water purification projects. Today, many producers of therapeutic plants dry and grind the leaves to be added to tea or porridge. At TRMEGA, it is mixed with three other plants (including the herb from Kagera discussed above) to make imarisha. TRMEGA shares seedlings with its members and sells them to support the organization's work.

As the immigrant histories of therapeutic plants in these gardens suggest, herbal producers are no more invested in the purity of nature than they are in the authenticity of the healer or the discreteness of institutions. Local Slow Food festivals do celebrate indigenous foods. Yet through a careful parsing of plants as "therapeutic," Tanzanians are mobilizing commitments to indigeneity toward new ethical-political negotiations. ${ }^{19}$ Some gardens share space with more recent hybrids such as banana stock from the USAID Tanzania Agricultural Productivity Program, or the many sorts of orange sweet potatoes that have made their way into the country through nutrition projects that have introduced a variety of nutrient-dense cultivars. Relations with plants are cultivated based on the ways that collaborations with them enable particular modes of exchanging, growing, eating, tasting, healing, communing, and decomposing. The qualities of the plants themselves matter. Mlonge, for instance, does not lend itself easily to plantation agriculture despite the ongoing efforts of many. The leaves are small and difficult to harvest en masse; they wilt quickly. One failed effort at large-scale production 
lies to the east, outside Tanga, where row upon row of trees stand unattended and unharvested. Mlonge's value emerges when it is enrolled in human projects by different means.

Relations among plants, as well as between plants and people, prove critical to decisions about which plants are brought in, cultivated, and catered to, and which plants are not. Not only are gardens as remedy ones that foster mutualist relations - nitrogen fixing, pesticide management, pollination, and so on - but they are also capable of holding surprises and remembering, even when people do not. Nguya and Machange illustrated this one day when walking through the garden of a member of one of the women's groups. They saw a vine growing among the more purposefully tended plants and asked the woman what she did with it. She told them that it was "just a weed.” Nguya revealed that she could eat the fruits of this wild cucumber plant, and Machange added that the leaves made a good vegetable. The woman tasted the plant; later, she ate the fruits and cooked the leaves. Soon, she was making a small income selling the leaves and seeds back to Nguya and Machange for Slow Food gardens and to others in local markets. The gardens here are weedy. Often blackjack or other medicinal herbs will be growing in the middle of a bed of another vegetable, or on the side of a tended row. Such weeds are left. These gardens are not plantations. The plants brought in must make affordances for, if not explicitly support, other life. The practices through which particular plants are folded into the space of these gardens cultivate plant relations, and therefore a plant politics.

These weedy natures defuse a politics of purity and, in so doing, the fantasies of salvation (or apocalypse) such a politics supports. Projects such as TRMEGA's make much more modest proposals about what it might mean to develop spaces with the capacity for growth or for what Anna Tsing $(2015,179)$ calls "resurgence." The work is patchy and uneven. It requires making arguments for care and healing, for taking positions and initiating action from some ground other than crisis (Roitman 2013). This ground is compost. In the gardens discussed here, compost is both practical consideration and a form of re-membering. Compost is that which fosters a process of living-through. It trains our attention on the ability of parts of the past that have been left behind, residues and scraps, to transform through specific entanglements into something other than themselvesand, if carefully tended, to transform into the components of rich healthy soil, the entanglement that grounds growth and other life. Compost re-members and in so doing, it decenters the work of crisis and its forms of forgetting. ${ }^{20}$ 
There are stakes in this turn. Compost constitutes a material, social, and ethical relation. For not all things compost and not all compost well. The stakes, however, rest in an ongoingness, not in an authenticity. They rest in the qualities of relations that support "making livable again" (Haraway 2016, 33). Plants can be localized over time by becoming other than themselves, by being turned under and becoming soil. Compost draws us toward accounts of pragmatic spaces of thoughtful entanglements with the potential for increased liveliness. Compost is not only a practice worthy of description but also an incitement to theory. ${ }^{21}$

Some of the most involved conversations between Ngyuga, Mwalyego, and the others with whom they collaborate concern composting: what to compost, where to put it, how to tend to it, and how to use it. In my first interview with Nguya, she emphasized compost as central to the identity of her garden, stating emphatically that they never use dawa za dukani, literally "store-bought medicines," referring to chemical fertilizers available at the market. Composting, which in practice includes the recycling of crop residues, food scraps, and animal waste, orients toward a "collective continuance" (Whyte 2018) of the vital forces that support ongoingness. In the process, it problematizes that which attenuates and diminishes these forces over time, or toxicity. On entering each of the gardens that we visited together, Nguya attends to the signs of composting: the pits or piles of organic matter in slightly shaded spaces, in different stages of decomposition, bearing evidence of regular turning. She asks questions and advises on how to foster the sorts of relations that lead to soil that can go on-systems of replenishment, practices of nourishment. As she builds new relations or starts to become more deeply involved with a garden, establishing composting routines and ensuring practices that regenerate the soil's fertility often demands significant time. Successful composting requires reflection and attention, even in her own garden and in those of longtime companions.

Composting involves cultivating thick relations. The greater the content of organic matter, the greater the capacities of the soil to retain water and nutrients, to make proximate those entanglements that support plants and a community of decomposer microorganisms. When these relations are attenuated - when plants are harvested and taken away, when plant matter is not turned back into the soil, when there has been a thinning of relations - then the structure and porosity of the soil becomes compromised. Composting proposes an ethic of return or, at least, of a regular turning. The past is turned in and under to cultivate an environment dense with matter and with the potential for transformative relations. 


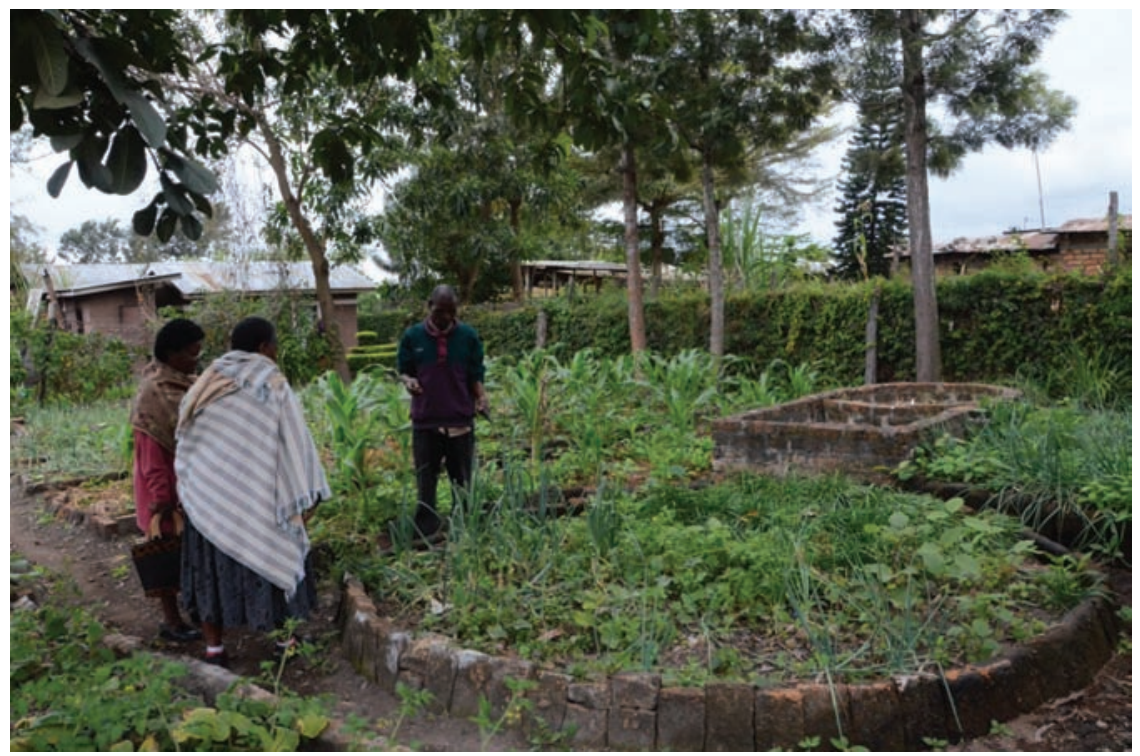

Figure 5. A discussion in the garden at TRMEGA headquarters in Maji ya Chai. The brick compost bin for both garden waste and kitchen scraps is visible on the right.

Photo by Stacey Ann Langwick.

The pleasures of composting rest in these interconnections, interpenetrations, and transformations. The stuff of the world must alter from itself, change from what it was: corn stalks, bean vines, fallen rotting tomatoes, spinach stems, and other debris from the garden and scraps from the kitchen left after human consumption. Exposure to living decomposers like bacteria, fungi, protozoa, algae, invertebrates, and insects triggers long and complex sequences of physical transformations: decomposition, mineralization, and humification. Composting calls for an ethics that rests in ontological dynamism. Our stakes in each other cannot be articulated through a loyalty or faithfulness to what one is; rather, the stakes consist in a commitment to becoming other - to becoming that through which other living might happen (Holbraad, Pedersen, and Viveiros de Castro 2014). ${ }^{22}$

\section{CONCLUSION}

For Tanzanians, modern bodies bear complicated toxic loads not only because of the dumping of capitalism's harmful by-products but also because of the very products that facilitate domestic life (plastics, kerosene), agriculture (pesticides, chemical fertilizers) and health (antiretrovirals, contraceptives). Dawa lishe 
is forged in this double bind. It problematizes toxicity as a way to think about the conditions under which life becomes attenuated, diminished, depleted, exhausted, drained away. The toxic is social (as with stigma) and environmental (as with chemical fertilizers). Producers of dawa lishe offer dried herbal formulasbut "not only" (see de la Cadena 2015, 13-28). They also intervene into the social and environmental conditions that attenuate life and diminish vitality.

In raising gardens as remedy, producers of therapeutic foods and nutritious medicines shift attention from the individual embodiments of plants and people to the ways that plants collaborate with people to make vital spaces that enable healing. Plants are not only agents with active ingredients, although both herbal producers and users are happy to fold in such articulations if available. Plants are not only resources to be capitalized on, although they do at times constitute a latent commons that offers the possibility of commodification. They are therefore not (or not only) anticommodities (see Scott 2009), even as they resist the forms of politics possible through stable trajectories of commodification (Glover and Stone 2018). In these gardens, therapeutic plants are never only resources to be harnessed for human need (corporeal, aesthetic, or economic); they are also collaborators in the making of nourishing and nourished spaces. ${ }^{23}$ In fact, plants become therapeutic as they move and work with people to create habitable spaces, pockets where people and plants mutually reinforce the cultivation of vitalities. ${ }^{24}$

Agricultural policies in Tanzania over the past fifty years have focused on cash-crop productivity as a way of navigating the country's position in the global economy. The gardens at TRMEGA disrupt the forms of scalability so critical to these dominant notions of development. They are designed for ongoingness, rather than scalability and maximum extraction. Gardeners eschew notions of transcendence through continual growth; they work within the impermanence, dependencies, and decompositions of plant and human life. Organizing their gardens around compost, they question how we problematize toxicity by pointing to the ways that people and plants navigate value within the dynamics of composition and decomposition. They do not ignore other framings - environmental destruction, chronic disease, or food insecurity - but they unsettle them by recognizing and folding in the temporalities of other urgencies. Such gardening projects think expansion with their plants; reproducibility here is about seed sharing, cuttings, and transplants. Health is about lushness, density, diversity, and the mutualisms it enables.

Many have cited the witticism, famously attributed to Fredric Jameson, that "it is easier to imagine the end of the world than to imagine the end of capitalism." 
In part, this failure of imagination is an effect of what (and who) we choose to think with. These gardens of therapeutic plants are not outside modes of capitalist extraction and world-making, but they do seek healing through ways that alter it and are alter to it (Viveiros de Castro 2012).

TRMEGA's engagement with food sovereignty movements, then, raises an interesting question about the sorts of sovereignty the organization imagines. From one angle, these gardens appear to democratize the means of therapeutic production. Indeed, knowledge of the ingredients in one's medicines, and the ability to make them, stand in stark contrast to most people's relationship to pharmaceuticals. These gardens also expand access to particular therapies, reclaiming the right to alternative options for treatment. By sharing cuttings, seeds, and transplants with each other, TRMEGA members and affiliates might be said to create and extend a form of the commons. In this reading, the commercialization of plant-based medicines hovers as the ultimate, if not inevitable goal. Sovereignty would seem to emerge through people's ability to determine what sorts of therapies are available, what they are composed of, how they are produced, and how they are distributed.

From another angle, however, the extension of these gardens results in more than a democratization of the means of production for herbal therapies, because the gardens themselves move the therapeutic value of the plants beyond the process of commoditization. Gardens cannot be explained away as apothecaries for the poor. In this reading, TRMEGA's work is not about control over the means by which therapeutic plants are turned into resources for the alleviation of human need, but rather about the creation of spaces that facilitate dynamic relations among plants, people, soil, and decomposers of various sorts, as well as the interpenetrations that might transform them. A plant's own capacity to reproduce is utilized in efforts to extend the gardens. None of the gardens stands as a model of some original or imagined garden. None is merely a concept. Rather, each constitutes an actual extension of other gardens, an extension of their social relations, physical matter, and storied histories. ${ }^{25}$ Not only does this move challenge a particular notion of ownership but also, as diverse temporal relations fold in on one another, it also troubles the very notion of an owner. Opened up to the indeterminacies of both subject and object, this version of sovereignty suggests the ability to shape the conditions of possibility for thriving and becoming - that is, the conditions of habitability.

Indeed, thinking with the edges of capitalism means, in part, thinking through toxicities as a condition of life to be navigated, shaped, and engaged, 
rather than as apocalypse or salvation. The ethics of these gardens grow in the relations and logics of dirt. They do not lend themselves easily to dystopic or utopic visions. They push against these "cramped spaces" (Povinelli 2016, 6) for argument and action. They are experiments in creating spaces for a new politics of habitability, one that continually asks: What kinds of lushness can be cultivated in twenty-first-century Tanzania? What relations enable bodies and landscapes to grow ampler, denser, more productive and more potent? Whose ongoingness and what forms of continuance do our gardens support?

\begin{abstract}
For Tanzanians, modern bodies bear complicated toxic loads not only because of the dumping of capitalism's harmful by-products but also because of the social-material effects of efforts designed to address insecurity, poverty, and disease. Dawa lishe (nutritious medicine) is forged in this double bind. Producers of dawa lishe problematize toxicity as the condition under which life is attenuated, diminished, depleted, exhausted, or drained away. Therapies attend not only to individual bodies but also to relations among people, plants, and the soil. The efficacy of herbal remedies and of gardens full of therapeutic foods and nutritious herbs rests in the cultivation of the forms of strength that make places, times, and bodies livable again (and again). This essay examines how Tanzanians are laboring over, and reflecting on, the toxic and its relationship to remedy and memory through dawa lishe. In the process, it argues, they are redefining healing through a politics of habitability. [toxicity; healing; body; plants; gardens; sustainable agriculture; ontologies; Africa]
\end{abstract}

\title{
NOTES
}

Acknowledgments The research on which this article is based was supported by the National Science Foundation and the Wenner-Gren Foundation, as well as by Cornell University through the Mario Einaudi Center for International Studies and the Institute for the Social Sciences. I was grateful for a generative and generous environment in which to write during my fellowship at the Society for the Humanities at Cornell University (2016-2017). The analysis developed through my extended participation in the Translating Vitalities working group, which was supported by the University of Chicago, the University of British Columbia, and the Wellcome Trust. The article also benefited from the feedback of many scholars at the annual meetings of the American Anthropological Association and the African Studies Association, as well as from presentations at the Society for the Humanities and the Institute for Comparative Modernities at Cornell University and the Department of History and Sociology of Science at the University of Pennsylvania.

1. Here, see Lyons 2016; Murphy 2017, 105-109; and Whyte 2018.

2. Michel de Certeau (1984) taught us that habitability is about the making of storied space, as well as the spatiality of stories. In The Practice of Everyday Life, he accounts for the ways that walkers make urban space habitable over and against the concept city of the planner, which is created from a view in the tower with the logics of efficiency and design. The walker creates spaces as she moves through the city, drawing with her not only maps but also memories and legends. The city unfolds through the movements of the walker as she is pulled down different paths by longings, nostalgia, and glimpses of 
beauty, or pushed by fear, dread, or boredom. The walker takes shortcuts (or long), breaking with the planners' trajectories and weaving more complicated, laden spaces. For de Certeau, the walker is seized on by the imagination, which creates spaces for return, spaces where the past can be acknowledged, its presence responded to. Without this ability to return, the city is not habitable. This article is also about movements that strive to remember and reorient toward the past through material entanglements in the present. In contrast to de Certeau's urban walker and that very human-centered story, however, I think through gardens and the labors of plants and people.

3. See Hamdy 2012 and Livingston 2012 on ways that the toxicity of pharmaceuticals is problematized elsewhere in Africa.

4. See Walter Stumpf's (2006) argument about the biomedical truism "the dose makes the medicine."

5. Consider, for instance, their impact on bodily life and household economies through hunger (Kalofonos 2010; Langwick 2015) and on political-economic positioning globally (Peterson 2014).

6. I am inspired here by Michel Foucault's (1985) ontological claim for ethical substance as the matter of the self on which ethical and moral discourse reflects. Ethical substance is that which demands reflection and work. Attending to this substance is what makes ethical subjects. Foucault argues that for the Greeks, this was bodily pleasure. The potency of dawa lishe resides in the way that it captures an active material-social space to work on an alternative ethical substance: toxicity.

7. Much of this literature is inspired by feminist, queer, critical race, and postcolonial theory. Shiloh Krupar's (2013) work reminds us that the impossibility of purity is not an issue of the so-called developing world. Yet Elizabeth Roberts (2017) does not let us forget that other ways of articulating boundaries (and managing the flow of substances in ways that constitute insides and outsides) remain important. The impossibility of purity does not mean that all entanglements are welcome.

8. One might argue that at the heart of interest in alternative modernities lay an attraction to the creative maneuvers of people outside of the United States and Europe to reject forms of purification that would marginalize them from discourse while simultaneously translating the institutions of modernity.

9. See Helen Tilley's (2004) and Louise White's (2004) contributions to the issue of Osiris on "Landscapes of Exposure," as well as Hecht 2012.

10. While pesticide and herbicide use is prevalent on small holdings, many report feeling ill after application (Ngowi et al. 2007).

11. In supporting of the government's 2006 National Biosafety Frameworks, which required the monitoring of genetically modified organisms, Chagula Mwita, Ken Hosea, and Masoud Muruke (2013) conducted a study to assess GMO contamination in both imported maize stocks and processed soybeans in the country.

12. In the interpretive social sciences, the demands of grappling with toxicity have incited the theorization of exposure. A central catalyst has been a special issue of $O$ siris edited by Gregg Mitman, Michelle Murphy, and Christopher Sellers (2004). See Fortun 2001; Petryna 2002; Fortun and Fortun 2005; Murphy 2006, 2017; Choy 2011; Chen 2012; Shapiro 2015; Alaimo 2016; and Haraway 2016. See also the series of essays on "Toxicity, Waste, and Detritus in the Global South: Africa and Beyond," edited by Pamila Gupta and Gabrielle Hecht (2017).

13. For more on the history of traditional healing in Tanzania, see Feierman 1974, 1990; Turshen 1984; and Langwick 2011a, 2011b, 2012.

14. In 2011, Tanzania launched a new process for the registration of healers, their premises, and their medicines. The national registrar of the council for traditional healers first recommended some of the herbal producers with whom I worked in northern Tanzania. She held them up to me as models for how healers might develop and in turn lead the development of traditional medicine. Yet others with whom I worked explicitly rebuffed the label of healer and state attempts to manage their practice and products through this 
category. Identifying as entrepreneurs, they were more likely to seek certification through the Small Industrial Development Organization.

15. See Feierman 1985 on the ways that healers were separated from their social basis of power.

16. I thank Steve Feierman for this point. As Brad Weiss (1996) has described, villages in this region comprise a cluster of household-based farms dominated by banana (the staple food crop) and coffee (the primary cash crop).

17. Helen's grandmother would have been unlikely to have access to farmland defined by the cultivation of the bananas by men. Yet she, like other women in Kagera, would have used the grasslands outside of the village to cultivate food and potentially medicines for family consumption and sale. Helen's establishment of TRMEGA echoes longstanding strategies by women in Kagera to generate possibilities within the frictions of patriarchal systems of land ownership (Weiss 1996).

18. See Archambault 2016 for a discussion on how affective encounters between people and plants in Mozambican gardens inspire reflections and reorientations that generate the possibility of new futures.

19. For an important argument on the political and ecological significance of native plants, see Mastnak, Elyachar, and Boellstorff 2014.

20. For Roitman 2013, this forgetting is that which articulates crisis as the point that requires radical epistemological revision, the rupture that justifies intervention and something new.

21. Here, I join K. Hall 2014, Puig de la Bellacasa 2015, Haraway 2016, and Lyons 2016.

22. This is also the logic of ancestors, of a dying in which one might return but not as one's self, not as human, not embodied. Ancestors lay claim to the living. They demand feeding, coaxing, appeasing, and relation. They compel actions that remember that embodied life was born from them. Compost proposes a theory of nonhuman ancestors to be fed, appeased, and coaxed into new relations that will protect and nourish.

23. As Natasha Myers $(2017,297)$ writes, "plants entice entire ecologies of other creatures to participate in their care and their propagation: they have the know-how to entrain others in the service of their rhythms, their wiles, and desires." See also Hustak and Myers 2012.

24. This account joins work in the emerging field of critical plant studies, which "challenges the privileged place of the human in relation to plant life" (Stark 2015, 180; see also Marder 2013).

25. Such gardens grow and extend, but they are not scalable (as with matsutake in Tsing 2015). Rather, they invite us to connect the histories of the making of economies of scale and the making of ecologies of scale. For gardens as storied space, see L. Hall 2015.

\section{REFERENCES}

Agard-Jones, Vanessa

2016 "Chemical Kin/Esthesia." Paper presented at the Annual Meeting of the American Anthropological Association, Minneapolis, Minn., November 18.

Alaimo, Stacy

2016 Exposed: Environmental Politics and Pleasures in Posthuman Times. Minneapolis: University of Minnesota Press.

Archambault, Julie Soleil

2016 "Taking Love Seriously in Human-Plant Relations in Mozambique: Toward an Anthropology of Affective Encounters." Cultural Anthropology 31, no. 2: 244 71. https://doi.org/10.14506/ca31.2.05.

Anwar, Farooq, Sajid Latif, Muhammad Ashraf, and Anwarul Hassan Gilani

2007 "Moringa oleifera: A Food Plant with Multiple Medicinal Uses." Phytotherapy Research 21, no. 1: 17-25. https://doi.org/10.1002/ptr.2023. 
Belem, Gisele

2009 "Mining, Poverty Reduction, the Protection of the Environment, and the Role of the World Bank Group in Mali.” In Mining in Africa: Regulation and Development, edited by Bonnie Campbell, 119-49. New York: Pluto Press.

Campbell, Linda, D. G. Dixon, and R. E. Hecky

2003 "A Review of Mercury in Lake Victoria, East Africa: Implications for Human and Ecosystem Health." Journal of Toxicology and Environmental Health, Part B 6 , no. 4: 325-56. https://doi.org/10.1080/10937400306474.

Chen, Mel Y.

2012 Animacies: Biopolitics, Racial Mattering, and Queer Affect. Durham, N.C.: Duke University Press.

Choy, Timothy

2011 Ecologies of Comparison: An Ethnography of Endangerment in Hong Kong. Duke University Press.

Clapp, Jennifer

1994 "The Toxic Waste Trade with Less-Industrialized Countries: Economic Linkages and Political Alliances." Third World Quarterly 15, no. 3: 505-518. https:// doi.org/10.1080/01436599408420393.

Cone, Marla

2009 "Should DDT Be Used to Combat Malaria?" Scientific American, May 4. https:// www.scientificamerican.com/article/ddt-use-to-combat-malaria.

de Certeau, Michel

1984 The Practice of Everyday Life. Translated by Steven Rendall. Berkeley: University of California Press. Originally published in 1980.

de la Cadena, Marisol

2015 Earth Beings: Ecologies of Practice Across Andean Worlds. Durham, N.C.: Duke University Press.

Feierman, Steven

1974 The Shambaa Kingdom: A History. Madison: University of Wisconsin Press.

1985 "Struggles for Control: The Social Roots of Health and Healing in Modern Africa." African Studies Review 28, nos. 2-3: 73-147. https://doi.org/10.2307/ 524604.

1990 Peasant Intellectuals: Anthropology and History in Tanzania. Madison: University of Wisconsin Press.

Fortun, Kim

2001 Advocacy after Bhopal: Environmentalism, Disaster, New Global Orders. Chicago: University of Chicago Press.

2012 "Ethnography in Late Industrialism." Cultural Anthropology 27, no. 3: 446-64. https: //doi.org/10.1111/j.1548-1360.2012.01153.x.

Fortun, Kim, and Mike Fortun

2005 "Scientific Imaginaries and Ethical Plateaus in Contemporary U.S. Toxicology." American Anthropologist 107, no. 1: 43-54. https://doi.org/10.1525/aa.2005. 107.1.043.

Foucault, Michel

1985 The History of Sexuality, Volume Two: The Use of Pleasure. Translated by Robert Hurley. New York: Pantheon. Originally published in 1984.

Glover, Dominic, and Glenn Davis Stone

2018 "Heirloom Rice in Ifugao: An 'Anti-Commodity' in the Process of Commodification.” Journal of Peasant Studies 45, no. 4: 776-804. https://doi. org/10.1080/03066150.2017.1284062.

Gupta, Pamila, and Gabrielle Hecht, eds.

2017 "Toxicity, Waste, and Detritus in the Global South: Africa and Beyond." Somatosphere series. http://somatosphere.net/toxicity.

Hall, Kim Q.

2014 “Toward a Queer Crip Feminist Food Politics.” philoSOPHIA 4, no. 2: 177-96. 
Hall, Laura

2015 “My Mother's Garden: Aesthetics, Indigenous Renewal, and Creativity.” In Art in the Anthropocene: Encounters Among Aesthetics, Politics, Environments, and Epistemologies, edited by Heather Davis and Etienne Turpin, 283-92. London: Open Humanities Press.

Hamdy, Sherine

2012 Our Bodies Belong to God: Organ Transplants, Islam, and the Struggle for Human Dignity in Egypt. Berkeley: University of California Press.

Haraway, Donna J.

2016 Staying with the Trouble: Making Kin in the Chthulucene. Durham, N.C.: Duke University Press.

Hecht, Gabrielle

2012 Being Nuclear: Africans and the Global Uranium Trade. Cambridge, Mass.: MIT Press.

Holbraad, Martin, Morten Axel Pedersen, and Eduardo Viveiros de Castro

2014 "The Politics of Ontology: Anthropological Positions." In "The Politics of Ontology," Theorizing the Contemporary series edited by Martin Holbraad and Morten Axel Pedersen, Cultural Anthropology website, January 13. http:// www.culanth.org/fieldsights / 462-the-politics-of-ontology-anthropologicalpositions.

Hustak, Carla, and Natasha Myers

2012 "Involutionary Momentum: Affective Ecologies and the Sciences of Plant/Insect Encounters." differences 23, no. 3: 74 118. https://doi.org/10.1215/104073911892907.

Kalofonos, Ippolytos Andreas

2010 “'All I Eat is ARVs': The Paradox of AIDS Treatment Interventions in Central Mozambique.” Medical Anthropology Quarterly 24, no. 3: 363-80. https:// doi.org/10.1111/j.1548-1387.2010.01109.x.

Krupar, Shiloh R.

2013 Hot Spotter's Report: Military Fables of Toxic Waste. Minneapolis: University of Minnesota Press.

Langwick, Stacey A.

2011a Bodies, Politics, and African Healing: The Matter of Maladies in Tanzania. Bloomington: Indiana University Press.

2011 b "Healers and Scientists: The Epistemological Politics of Research about Medicinal Plants in Tanzania, or 'Moving Away from Traditional Medicine.'” In Evidence, Ethos, and Experiment: The Anthropology and History of Medical Research in Africa, edited by P. Wenzel Geissler and Catherine Molyneux, 263-95. New York: Berghahn.

2012 "The Choreography of Global Subjection: The Traditional Birth Attendant in Contemporary Configurations of World Health." In Medicine, Mobility, and Power in Global Africa: Transnational Health and Healing, edited by Hansjörg Dilger, Abdoulaye Kane, and Stacey A. Langwick, 31-59. Bloomington: Indiana University Press.

2015 "Partial Publics: The Political Promise of Traditional Medicine in Africa." Current Anthropology 56, no. 4: 493-514. https://doi.org/10.1086/682285.

Latour, Bruno

1993 We Have Never Been Modern. Translated by Catherine Porter. Cambridge, Mass.: Livingston, Julie Harvard University Press. Originally published in 1991.

2012 Improvising Medicine: An African Oncology Ward in an Emerging Cancer Epidemic. Durham, N.C.: Duke University Press. 
Lyons, Kristina Marie

2016 "Decomposition as Life Politics: Soils, Selva, and Small Farmers under the Gun of the U.S.-Colombia War on Drugs." Cultural Anthropology 31, no. 1: 56-81.

Marder, Michael https://doi.org/10.14506/ca31.1.04.

2013 Plant-Thinking: A Philosophy of Vegetal Life. New York: Columbia University Press. Mastnak, Tomaz, Julia Elyachar, and Tom Boellstorff

2014 “Botanical Decolonization: Rethinking Native Plants." Environment and Planning D 32, no. 2: 363-80. https://doi.org/10.1068/d13006p.

Minter, Adam

2016 "The Burning Truth Behind an E-Waste Dump in Africa." Smithsonian, January 13. https://www.smithsonianmag.com/science-nature/burning-truth-behind-ewaste-dump-africa-180957597.

Mitman, Gregg, Michelle Murphy, and Christopher Sellers, eds.

2004 "Landscapes of Exposure: Knowledge and Illness in Modern Environments." Special issue of Osiris, no. 19.

Murphy, Michelle

2006 Sick Building Syndrome and the Problem of Uncertainty: Environmental Science, Technoscience, and Women Workers. Durham, N.C.: Duke University Press.

2017 The Economization of Life. Durham, N.C.: Duke University Press.

Mwegoha, W. J. S., and C. Kihampa

2010 "Heavy Metal Contamination in Agricultural Soils and Water in Dar es Salaam City, Tanzania." African Journal of Environmental Science and Technology 4: 76369. https://www.ajol.info/index.php/ajest/article/view/71346.

Mwita, Chagula A., Ken M. Hosea, and Masoud H. Muruke

2013 "Assessment of Genetic Modification in Imported Maize (Zea mays) Seeds and Processed Soybean (Glycine max) Foods in Tanzania.” Journal of Chemical, Biological and Physical Sciences, Section B 3, no. 4: 2809-2827.

Myers, Natasha

2017 "From the Anthropocene to the Planthroposcene: Designing Gardens for Plant/ People Involution." History and Anthropology 28, no. 3: 297-301. https://doi. org/10.1080/02757206.2017.1289934.

Ngowi, A. V. F., T. J. Mbise, A. S. M. Ijani, L. London, and O. C. Ajayi

2007 "Smallholder Vegetable Farmers in Northern Tanzania: Pesticides Use Practices, Perceptions, Cost and Health Effects." Crop Protection 26, no. 11: 1617-24. https://doi.org/10.1016/j.cropro.2007.01.008.

Peterson, Kristin

2014 Speculative Markets: Drug Circuits and Derivative Life in Nigeria. Durham, N.C.: Duke University Press.

Petryna, Adriana

2002 Life Exposed: Biological Citizens after Chernobyl. Princeton, N.J.: Princeton University Press.

Povinelli, Elizabeth A.

2016 Geontologies: A Requiem to Late Liberalism. Durham, N.C.: Duke University Press.

Puig de la Bellacasa, Maria

2015 "Making Time for Soil: Technoscientific Futurity and the Pace of Care." Social Studies of Science 45, no. 5: 691-716. https://doi.org/10.1177/ 0306312715599851.

Redfern, Paul

2010 “EU, U.S. Dumping Toxic Waste in Africa." East African, July 5. http:// www.theeastafrican.co.ke/news/EU-US-dumping-toxic-waste-in-Africa/2558951790-385m1f/index.html. 
Roberts, Elizabeth F. S.

2017 "What Gets Inside: Violent Entanglements and Toxic Boundaries in Mexico City." Cultural Anthropology 32, no. 4: 592-619. https://doi.org/10.14506/ ca32.4.07.

Roitman, Janet

2013 Anti-Crisis. Durham, N.C.: Duke University Press.

Saas, Christine

2014 "How a Garden Changed My Life." Slow Food Foundation for Biodiversity website, September 2. https://www.fondazioneslowfood.com/en/come-unorto-mi-ha-cambiato-la-vita.

Schmidt, Charles W.

2006 "Unfair Trade: e-Waste in Africa." Environmental Health Perspectives 114, no. 4: A232-35. https://www.ncbi.nlm.nih.gov/pmc/articles/PMC1440802.

Scott, James C.

2009 The Art of Not Being Governed: An Anarchist History of Upland Southeast Asia. New Shapiro, Nicholas Haven, Conn.: Yale University Press.

2015 "Attuning to the Chemosphere: Domestic Formaldehyde, Bodily Reasoning, and the Chemical Sublime." Cultural Anthropology 30, no. 3: 368-93. https:// doi.org/10.14506/ca30.3.02.

Sharma, Alok, C. Shanker, Lalit Kumar Tyagi, Mahendra Singh and Ch. V. Rao

2008 "Herbal Medicine for Market Potential in India: An Overview." Academic Journal of Plant Science 1, no. 2: 26-36.

Shotwell, Alexis

2016 Against Purity: Living Ethically in Compromised Times. Minneapolis: University of Minnesota Press.

Stark, Hannah

2015 “Deleuze and Critical Plant Studies." In Deleuze and the Non/Human, edited by Jonathan Roffe and Hannah Stark, 180-96. New York: Palgrave Macmillan.

Stumpf, Walter E.

2006 “The Dose Makes the Medicine." Drug Discovery Today 11, nos. 11-12: 550-55. https://doi.org/10.1016/j.drudis.2006.04.012.

Tsing, Anna Lowenhaupt

2015 The Mushroom at the End of the World: On the Possibility of Life in Capitalist Ruins. Princeton, N.J.: Princeton University Press.

Tilley, Helen

2004 "Ecologies of Complexity: Tropical Environments, African Trypanosomiasis, and the Science of Disease Control Strategies in British Colonial Africa, 1900-1940.” Osiris 19: 21-38. https://doi.org/10.1086/649392.

Tilman, David, Joseph Fargione, Brian Wolff, Carla D’Antonio, Andrew Dobson, Robert

Howarth, David Schindler, William H. Schlesinger, Daniel Simberloff, and Deborah

Swackhamer

2001 "Forecasting Agriculturally Driven Global Environmental Change." Science 292: 281-84. https://doi.org/10.1126/science.1057544.

Turshen, Meredeth

1984 The Political Ecology of Disease in Tanzania. New Brunswick, N.J.: Rutgers University Press.

Viveiros de Castro, Eduardo

2012 “'Transformação' na antropologia, transformação da 'antropologia.” Mana 18, no. 1: 151-72. https://doi.org/10.1590/S0104-93132012000100006.

Weiss, Brad

1996 The Making and Unmaking of the Haya Lived World: Consumption, Commoditization, and Everyday Practice. Durham, N.C.: Duke University Press. 
White, Louise

2004 "Poisoned Food, Poisoned Uniforms, and Anthrax: Or, How Guerillas Die in War.” Osiris 19: 220-33. https://doi.org/10.1086/649403.

Whyte, Kyle Powys

2018 "Food Sovereignty, Justice, and Indigenous Peoples: An Essay on Settler Colonialism and Collective Continuance." In The Oxford Handbook on Food Ethics, edited by Anne Barnhill, Mark Budolfson, and Tyler Doggett, 345-66. New York: Oxford University Press. 